\title{
Huomioita kasvatuksen, sivistyksen ja sosialisaation välisistä suhteista
}

\author{
Ari Kivelä
}

"Keskeinen käsitteellinen erottelu, johon nojaudun artikkelissani (1997), on käsitteiden kasvatus ja sivistys välinen erottelu. Jaottelu on löydettävissä suhteellisen selkeässä muodossa: kasvatus on tekokategoria ja sivistys prosessikategoria. Teko- ja prosessikategorioiden välinen erottelu on ulotettavissa myös kasvatuksen ja sosialisaation välisen suhteen tarkasteluun. Sosialisaatiohan määritellään yleisimmin juuri prosessiksi. Yhtä vähän kuin sivistys on kasvatuksen yläkäsite, voi sosialisaatiokaan sitä olla", kirjoittaa Ari Kivelä.

Tarkastelen muutamia artikkelissa Kasvatusta vai sosialisaatiota esitettyjä väitteitä. Ikonen ottaa kriittisen tarkastelunsa kohteeksi artikkelini Pedagoginen toiminnanteoria ja sosialisaatioteoria (Kivelä 1997), jossa hahmottelin pedagogisen toiminnanteorian keskeisiä käsitteellisiä periaatteita ja pedagogisen toiminnanteorian ja interaktionistisen sosialisaatiokonseption välistä suhdetta. Kyseisessä artikkelissani tarkastelin sitä, mitä käsitteellä pedagoginen toiminta voidaan kasvatustieteellisessä kielenkäytössä tarkoittaa.

Hahmottelemani käsitteellinen rekonstruktio perustuu erityisesti saksalaisessa kasvatustieteessä virinneeseen keskusteluun, jossa on nostettu esiin keskeisiä modernin pedagogisessa teoriaperinteessä vaikuttaneita käsitteitä. Tällöin on korostunut ajatus siitä, että modernista pedagogisesta ajattelutraditiosta on mahdollista työstää esiin käsitteitä ja ajattelumalleja, joiden myötä pedagogiset asiasisällöt olisivat tarkasteltavissa kohdeherkemmin. Artikkelini taustaoletus oli, että juuri näiden käsitteiden ja ajattelumallien, joiden kehitys on jäljitettävissä modernin pedagogisen ajattelun syntykontekstiin 1700-1800lukujen taitteeseen, varassa on muotoiltavissa käsitteellinen rekonstruktio kasvatustieteen tutkimuskohteesta, jota voidaan kutsua pedagogi- 
seksi toiminnaksi (saks. pädagogisches Handeln).

Tähän nojautuen tarkastelin artikkelissani muutamia interaktionistisen sosialisaatiokonseption ja pedagogisen toiminnanteorian välisiä temaattisia yhteyksiä. Tarkoituksenani oli alustavasti hahmotella pedagogisen käsitteistön avulla näkökulmia sosialisaatiokonseption teoreettisiin ongelmiin ja samalla myös monitieteistä perspektiiviä yhteiskunnallistetun subjektin kehittymisen ongelmakenttään (mt. 49-56).

\section{Pedagogisen toiminnan- teorian lähtökohtia}

$\mathrm{T}$ arkastelen seuraavaksi muutamia pedagogisen toiminnanteorian keskeisiä oletuksia, joita Ikonen referoi virheellisesti tulkiten tekstiäni omavaltaisella tavalla. Ikonen väittää asiayhteydestä irrotettuun sitaattiin nojautuen, että oletus sivistyksellisyydestä (BILDSAMKEIT) on pohjimmiltaan sivistysasteen ja laadun arvioimista. Edelleen hän väittää, että tähän liittyisi oletus ideaalista sivistyksellisyydestä ja jopa ideaali ihmiskuva, jota kohden ihmiset ovat pyrkimässä. Artikkelissani en ole esittänyt mitään tällaista. Puhuessani sivistyksellisyydestä kasvattajan oletuksena (mt. 40) viittaan siihen, että pedagogisesti toimivalla täytyy olla käsityksiä kasvatettavan sivistyksellisyydestä. Tähän kuuluvat esimerkiksi pedagogisesti toimivan enemmän tai vähemmän onnistuneet oletukset kasvavan oppimis- ja kehityspotentiaaleista, valmiuksista ja ennakoitavissa olevasta kehityksestä. Ilman tuollaisia oletuksia käytännöllinen pedagoginen toiminta ei olisi ylipäätään mahdollista. Nämä oletukset ovat kuitenkin vain kasvattajan tekemiä tulkintoja ja käsityksiä kasvavan sivistyksellisyydestä ja siitä, kuinka se määrittää konkreettista pedagogista toimintatilannetta ja kuinka kasvattajan on otettava se omassa toiminnassaan huomioon.

$\mathrm{K}$ asvattajan tulkinta kasvavan sivistyksellisyydestä ei ole kuitenkaan identtinen kasvavan sivistyksellisyyden kanssa. Tässä pedagogisen vuorovaikutuksen spesifiin tavoitteellisuuteen ja logiikkaan liittyvässä merkityksessään sivistyksellisyys on pikemminkin käytännöllis-pedagoginen fiktio, joka on välttämätön pedagogiselle toimijalle itselleen ja toiminnan suuntaamiselle ( $\mathrm{mt}$ 54; Kivelä 1998; Oser 1994). Se ei ole sivistyksellisyyden kuvaus, vaan toiminnan kannalta välttämätön oletus, joka sitoo konkreettisen sivistyksellisyyden pedagogiseen vuorovaikutukseen (Benner 1991).

Tätä käytännöllistä näkökulmaa ei kuitenkaan pidä sekoittaa Ikosen tavoin sivistyksellisyyteen ihmisen maailmassa olemisen perustavana ehtona ja siihen, millaista roolia se pedagogisessa toiminnanteoriassa näyttelee. Kuten erityisesti Benner korostaa, emme voi koskaan todella tietää, mitä sivistyksellisyys on. Se on vain ymmärrettävä ihmisen maailmassa olemisen mahdollistavaksi periaatteeksi. On toki perusteltua olettaa, että ihmisellä on sekä reseptiivinen kyky määrittyä ympäristönsä kautta että kyky oman spontaniteettinsa varassa määrittää ympäristöään. Sivistyksellisyys yhtäaikaisena reseptiivisyytenä ja spontaniteettina mahdollistaa ihmisen vastavuoroisen maailmassa olemisen ja siten sivistysprosessin. Siitä ei voi kuitenkaan johtaa erityistä ihmistä koskevaa ihannetta, joka olisi ymmärrettävissä kasvatuksen tavoitteeksi. Tässä merkityksessään se viittaa vain ihmisen avoimeen määrittelemättömään määräytyneisyyteen, joka mahdollistaa erilaisten inhimillisen olemassaolon muotojen historiallisen ja empiirisen todellistumisen. Ihmistä koskevat ideaalit ovat puolestaan historiallisia yrityksiä käsitteellistää ihmisen sivistyksellisyyttä.

Qivistyksellisyys ei siis ole ontologisoitavissa Oietyksi ihmisideaaliksi tai ihmiskuvaksi. Tässä suhteessa sivistyksellisyyden käsitettä voidaankin luonnehtia jopa ontologia- ja metafysiikka-

Yritykset määritellä ihmiskuvia

ja ideaaleja ovat aina risti-

riidassa sivistyksellisyyden

yleisen periaatteen kanssa ja

siten pohjimmiltaan mahdotto-

man tehtävän edessä. 
kriittiseksi. Yritykset määritellä ihmiskuvia ja ideaaleja ovat aina ristiriidassa sivistyksellisyyden yleisen periaatteen kanssa ja siten pohjimmiltaan mahdottoman tehtävän edessä. Koska ihminen sivistyksellisenä olentona tuottaa toiminnassaan itse oman eksistenssinsä, ei tämän maailmassa oleminen ole koskaan periaatteessa määritettävissä jonkin konkreettisen sivistysideaalin avulla. (Benner 1995, 45; 152-156; 166-168.) Yllättävää kyllä, kirjoittajan esittämän kritiikin lähtökohtana on oletus siitä, että luonnostelemassani pedagogisen toiminnan teoriassa pyrittäisiin esittämään objektiivisia ulkoisia ja normatiivisia sivistysideaaleja tai kasvatustavoitteita.

$\mathrm{I}_{\mathrm{t}}^{\mathrm{k}}$ konen ilmeisesti ymmärtää esittelemäni itsetoiminnan käsitteen persoonallisen autonomian tai kriittisyyden merkityksessä tulkiten sitä niin, että se implikoisi kasvatuksellisen vaikutuksen tavoitteeksi konkreettisen normatiivisen ideaalin itsenäisestä yksilösubjektista, joka olisi ymmärrettävissä historiallisesta määräytyneisyydestä vapaaksi toimijaksi. Tässä hän syyllistyy kuitenkin karkeaan kategoriavirheeseen. Persoonallinen autonomia tai kriittisyys ovat toki ymmärrettävissä erityisiksi sivistysideaaleiksi, joilla ainakin valistuksen perinnössä katsotaan olevan oma kiistaton arvonsa. Itsetoiminta on kuitenkin toisen tason käsite. Sen juuret palautuvat Johann Gottlieb Fichten filosofiaan (Benner 1991, 64; ks. Kivelä 1998; 2000), jossa itsetoiminta (SELBSTTÄTIGKEIT) on ylipäätään inhimillisen tietämisen ja toiminnan välttämätön mahdollisuusehto. Tästä seuraa myös se, että esimerkiksi oppimispro-

\section{Kasvatuksellisen vaikutuksen}

tehtävänä on herättää kasvavan oma tietämis- ja oppimisprosessi. Koska oppimis-, ja siten sivistysprosessit perustuvat kasvavan omaan toimintaan, niiden tulokset eivät ole koskaan täysin ennustettavissa tai kasvatuksellisin teoin kontrolloitavissa. sessit on ymmärrettävä luonteeltaan itsetoiminnallisiksi (Benner 1991, 63-73; 1995, 58). Fichten ajattelun merkittävintä kasvatus- ja sivistysteoreettista antia on huomio kasvatuksellisen vaikutuksen luonteesta. Hänelle kasvatus oli vaatimusta itsenäiseen toimintaan (Aufforderung zur Selbsttätigkeit) (ks. Kivelä 1998; 2000).

Vaatimus on eräänlainen kimmoke, joka mahdollistaa sen, että kasvava voi realisoida oman potentiaalisen aktiivisuutensa konkreettisessa toiminnassa. Kasvatuksellisen vaikutuksen tehtävänä on herättää kasvavan oma tietämis- ja oppimisprosessi. Koska oppimisprosessit - ja siten sivistysprosessit - perustuvat kasvavan omaan toimintaan, niiden tulokset eivät ole koskaan täysin ennustettavissa tai kasvatuksellisin teoin kontrolloitavissa. (ks. Benner 1991, 265-275.) Vaikka moraalis-poliittiset ideaalit, kuten autonomia tai kriittisyys edellyttävät todellistuakseen itsetoiminnallisuutta, ei se ole kuitenkaan näiden ideaalien todellistumisen tae. Ihminen voi omassa toiminnassaan realisoida muitakin maailmassa olemisen tapoja. Pedagoginen toiminnanteoria, joka ottaa lähtökohdakseen itsenäisen toiminnan ja sivistyksellisyyden periaatteet, ei voi enää esittää erityisiä normatiivisia sitovia kannanottoja oletetuista sivistysideaaleista olematta sisäisesti ristiriitainen. (Benner 1991; 115-123; 126-141; 1995, 152, 155-156; 159; 163-168. $)^{1}$

$\mathrm{I}^{\mathrm{s}}$ kosen oletus hahmottelemani pedagogisen toiminnanteorian sidoksisuudesta moraalis-poliittisiin ihmisideaaleihin perustunee - ainakin osittain - virheelliseen tulkintaan artikkelistani (Kivelä 1997, 50-56 ), missä tarkastelin kriittisinteraktionistisen sosialisaatiokonseption systemaattisia ongelmia ja teoreettisia umpikujia. $\mathrm{Ne}$ ovat seurausta pyrkimyksestä kytkeä toisiinsa yhtäältä modernin perinteestä nouseva ajatus autonomisesta ja kriittisestä subjektista ja toisaalta oletus siitä, että vuorovaikutus ja siten viime kädessä jokin oletettu - yksilön ylittäväksi ajateltavissa oleva - kielellinen struktuuri tai sääntöjärjestelmä määrittää yksilöllistä itse- ja maailmatulkintaa, kun yksilö on ensin oppinut tai sisäistänyt kyseisen struktuurin tai säännöstön. (Frank 1991, 224; 455-457; vrt. Habermasin 1989, 187-241; Tugendhat 1993.) 
Intersubjektiiviseen ajattelumalliin sisältyy siis oletus sääntöjärjestelmän sisäistämisestä edellytyksenä yksilön refleksiivisen itse- ja maailmasuhteen sekä yksilöllisen autonomian kehittymiselle. Lähinnä filosofisessa keskustelussa tätä on pidetty ongelmallisena. Vahvoista nominalistisista ja/tai kielibehavioristisista premisseistään interaktionistinen näkemys ei nimittäin kykene tematisoimaan sitä, kuinka kielellisen sisäistämisprosessin tuloksena voi kehittyä sellainen yhteiskunnallistettu subjekti, joka on luonnehdittavissa samalla myös autonomiseksi ${ }^{2}$ yksilöksi. Epäselväksi jää nimittäin se, miten subjekti - opittuaan reagoimaan välittömästi tietyllä kielellisellä ilmauksella omaan mentaalista tilaa tai ulkoista todellisuutta koskevaan havaintoon - voi olla ymmärrettävissä kyseisen ilmauksen itsenäiseksi tuottajaksi, puhumattakaan siitä, miten hän voi aktiivisesti muokata ja kehittää kielellisiä merkityksiä ja tulkita siten todellisuutta uudella ja luovalla tavalla. Pidettäessä johdonmukaisesti kiinni intersubjektivismille välttämättömästä nominalistista pohjavireestä vaikuttaa kielellinen ilmaus olevan lähinnä opittu reaktio tai sisäistetty toimintamalli, joka yhdistyy tiettyyn havaittavaan ja tunnistettavaan kokemukseen tietyn kielellisen säännön tai rakenteen mukaisesti. (Frank 1991, 69-73; 170-171; 176; 218; 224; 1986, 101-103; 83-89; 119-130.)

Tämä periaatteellinen problematisointi, joka nousee subjekti-/tietoisuusfilosofian ja lingvistisen/intersubjektivistisen käänteen välisen vastakkainasettelun perusteita koskevasta keskustelusta, on ulotettavissa myös sosialisaatioteorian peruskysymyksiin (Kivelä 1997). Tällöin ongelmaan on mahdollista etsiä ratkaisua pedagogisen toiminnanteorian näkökulmasta. Vaikka intersubjektiviteetti ja vastavuoroinen kommunikaatio nähdäänkin yksilöllistymisen mediumina (Habermas 1989), perustuu intersubjektiviteetti kuitenkin yhteisesti jaettuihin merkityksiin, siis semanttis-veritatiiviseen symmetriaan. Sen rakentumisen edellytyksenä näyttää ideaalityyppisesti olevan se, että potentiaalinen puhuja/toimija oppii reagoimaan omiin kokemuksiinsa yhteisesti jaettujen kielellisten konventioiden mukaisesti. Tämä prosessi on ymmärrettävissä luonteeltaan yksisuuntaiseksi. Siinä potentiaalinen puhe- ja toimintakykyinen subjekti sisäistää toisen tai kolmannen perspektiivistä esitetyn reaktion, joka kohdistuu hänen omaan - tosin toisen tai kolmannen perspektiivistä - identifioitavissa olevaan mentaaliseen tilaan tai kokemukseen, omaksi reaktiokseen. Tällöin subjekti oppii tietyn kielellisen konvention (so. kulttuurisesti annetun tavan käyttää ilmauksia), joka määrittää sitä, minkä merkityksellisen ilmauksen subjekti myöhemmin liittää kyseiseen mentaalisen tilaan tai kokemuksen. (ks. Tugendhat 1993, 88-90, 94; 114-136.) Näin siis kielelliset konventiot määrittävät subjektin tapoja tulkita ja ymmärtää maailmaa (Frank 1985; 1991).

Myös Ikonen sortuu samaan ongelmaan. Yhtäältä hän väittää, että sosialisaatio on vastavuoroinen prosessi, jossa yksilö aktiivisesti toimii maailmassa eikä siten yksipuolisesti sosiaalistu vallitsevaan kulttuuriseen kontekstiin. Toisaalta kirjoittaja esittää viitatessaan erityisesti kielellisyyden kieltämättä perustavaan merkitykseen sosialisaatioprosessissa: "On tosin tähdennettävä, että tältä osin sosialisaatioprosessi on melkoisen yksisuuntainen: kieltä omaksuessaan yksilö on pääasiassa vastaanottava osapuoli.“ Ongelmaksi jää, millainen tapahtuma on kuvattavissa yhtä aikaa vastavuoroiseksi ja yksisuuntaiseksi.

Interaktionistisen sosialisaatioteorian ongelmaan voidaan hahmotella kasvatus- ja sivistysteoreettisesta näkökulmasta seuraavaa ratkaisua. Kielellisten ilmausten oppimisen kuvaaminen tapahtuvaksi interpersoonallisessa suhteessa toisen tai kolmannen persoonan perspektiivin sisäistämisen kautta on ymmärrettävissä pedagogisen suhteen tai pedagogisen interaktiotapahtuman malliksi. Se tosin sisältää pedagogisen toiminnanteorian näkökulmasta kasvatusteoreettisen sokean pisteen. Mikäli ymmärrämme kasvatuksellisen vaikutuksen vaatimuksena itsenäiseen toimintaan, olisi ilmeisesti jo itse kielen oppiminen ymmärrettävä luonteeltaan luovaksi ja uusia merkitysmahdollisuuksia avaavaksi tapahtumaksi, jossa ei vain siirretä kasvavalle tiettyä kielellistä konventiota. Kasvatus ei siis ole luonnehdittavissa semanttisen symmetrian synnyttämiseksi tai ylläpitämiseksi. (Mollenhauer 1982, 30-31; ks. myös Frank 1991, 249; Kivelä 1998.) 
Teko- ja toimintakategorioiden välinen erottelu pedagogisen toiminnanteorian lähtökohtana

$\mathrm{K}$ uten jo artikkelissani (1997) esitin, on kaszatuksen ja sosialisaation välistä suhdetta syytä tarkastella teon ja prosessin välisen analyyttisen erottelun kautta. Nojaudun erityisesti Jürgen Oelkersin esittämiin näkemyksiin, joiden mukaan pedagogisen toiminnanteorian lähtökohtana olisi erottelu teon (HANDLunG) ja prosessin (Prozess) käsitteiden välillä. Pedagogisten teorioiden keskeinen ongelma on se, ettei niissä eroteta analyyttisesti toisistaan teko- ja prosessikategorioita. Ikosen tapa tarkastella käsitteiden kasvatus ja sosialisaatio välistä suhdetta perustuu kykenemättömyyteen tehdä tämä käsitteellinen erottelu. Osin tämä palautunee sosialisaation käsitteen häilyvään käyttötapaan, jolle on ominaista sosialisaation ymmärtäminen yhtäältä jatkuvana prosessina ja toisaalta taas yksilöitävissä olevan sosialisaatioagentin tekoihin viittaavana kategoriana.

Ikonen väittää virheellisesti, että edustamassani positiossa "kasvatus kuvataan sivistysprosessina". Itse asiassa keskeinen käsitteellinen erottelu, johon artikkelissani nojaudun, on käsitteiden kasvatus ja sivistys välinen erottelu. Nojaudun sekä klassisen pedagogisen tradition tarjoamiin lähtökohtiin (ks. esim. Benner 1991) että Jürgen Oelkersin kehittelyihin ja ymmärrän tämän jaottelun teko- tai prosessikategorioiden välisenä jaotteluna. Vaikka Oelkersin huomioiden taustalla onkin 1970- ja 80-luvuilla käyty toiminnanteoreettinen keskustelu ja erityisesti analyyttisen kasvatusfilosofian kritiikki $(1985,31)$, on toiminta- ja prosessikäsitteiden välinen erottelu "erittäin traditionaalinen", sillä "klassista pedagogista teoriaa on aina määrittänyt se, että toiminta- ja prosessiaspekteja koskevat lausumat ovat kietoutuneet toisiinsa (...)“ (Oelkers 1985, 234235).Tämä jaottelu on löydettävissä suhteellisen selkeässä muodossa käsitteiden kasvatus ja sivistys välisessä erottelussa: kasvatus on tekokategoria ja sivistys prosessikategoria. (Oelkers 1982, 160; 172-177; 1985, 212-214.)

Oelkersin mukaan käsitteellinen jaottelu teko- ja prosessikategorioihin on pedagogisen toiminnanteorian ja pedagogisen toiminnan käsitteen kannalta perustava $(1985,209 ; 227)$. Hänen mukaansa pedagogista toimintaa koskeviin teoretisointeihin on sisältynyt aina teko- ja prosessikäsitteitä, tosin niin, että pedagogiset teoriat yleensä painottavat jompaa kumpaa näistä näkökulmista. Merkille pantavaa kuitenkin on, ettei pedagoginen toiminta ole mielekkäästi tarkasteltavissa joko teko- tai prosessikäsitteiden perspektiivistä, vaan tarkastelussa täytyy ottaa huomioon molemmat sekä näiden välinen suhde (mt. 234).

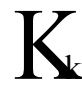

äsitettä sivistys käytetään teoreettisessa kesustelussa yleisimmin juuri prosessikategoriana. Sillä viitataan yksilön omassa toiminnassaan realisoimaan, ajallisesti jäsennettävissä olevaan jatkumoon. Se rakentuu perättäisten tilojen muodostamaksi kokonaisuudeksi, jonka eri vaiheet ovat erotettavissa toisistaan. Vaiheet perustuvat yksilön omassa maailmasuhteessaan saamiin kokemuksiin ja rakentuvat näiden kokemusten varassa. Yksilön sivistysprosessista voidaan puhua periaatteessa silloin, kun ymmärrämme yksilön elämänhistorian vaiheittain etenevänä jatkumona, jossa eri vaiheissa $\left(t^{1}, t^{2}, t^{3} \ldots\right)$ eri tavoin rakentuneet maailmasuhteet määrittävät yksilön maailmasuhdetta hetkellä $\mathrm{t}^{\mathrm{n}}$, tosin ei rakenteellisen determinismin mielessä, vaan niin, että aikaisemmissa maailmasuhteissa saatujen kokemusten pohjalta on aina myös mahdollista konstituoida uusia maailmasuhteita, joissa uudet kokemukset ja sitten uudet sivistysprosessin tilat tulevat mahdollisiksi. Oelkers liittää prosessikäsitteisiin oletuksen siitä, että prosessi rakentuu yksilön oman toiminnan kautta tämän vastavuoroisessa kokemuksellisessa suhteessa maailmaan. Lisäksi prosessi on luonteeltaan jatkuva. (Oelkers 1982, 175-176; 1985, 257-258.) Tekokategoriat puolestaan viittaavat kasvatusakteihin, joilla pyritään vaikuttamaan edellä mainittuun prosessiin ${ }^{3}$ kasvatuksellisin keinoin tiettyjen tavoitteiden saavuttamiseksi. Kasvatusteot ovat suhteessa prosessiin aina ajallisesti ja paikallisesti rajattavissa, niillä on määriteltävissä ja identifioitavissa oleva alku ja loppu, kun taas sivistys on ihmisen koko elämän läpäisevä prosessi.(Oelkers 1982, 173; 177; 1985, 224-225.) 
Kasvatusteot ovat suhteessa

prosessiin aina ajallisesti ja

paikallisesti rajattavissa, niillä

on määriteltävissä ja identifioi-

tavissa oleva alku ja loppu, kun

taas sivistys on ihmisen koko

elämän läpäisevä prosessi.

$\mathrm{M}^{\mathrm{i}}$ ikäli yksinkertaistamme pedagogisen toimintatilanteen kasvattajan ja kasvatettavan välisen suhteen tarkasteluksi, voimme vielä täsmentää teko- ja prosessikategorioiden välistä suhdetta. Teko- ja prosessikategoriat mahdollistavat pedagogisen toimintatilanteen tarkastelun kahdesta eri näkökulmasta, jolloin toimijaperspektiivi erottaa nämä kaksi kategoriaa toisistaan. Prosessikategorioista käsin kohdistuu pedagogisen toimintatilanteen tarkastelu siihen, kuinka kasvatettava määrittää omalla tavoitteellisella aktiviteetillaan pedagogisia tilanteita. Tähän voidaan liittää myös oletus siitä, että pedagogiset vaikutukset realisoituvat vasta oppivan yksilön omassa toiminnassa ja perustuvat siten hänen omiin kokemuksiinsa. Tekokategorioista käsin pedagogisen toiminnan tarkastelun lähtökohtana ovat kasvattajan teot, joilla tämä pyrkii vaikuttamaan prosessiin. Pedagogista toimintaa määrittää näin yhtäältä kasvattajan ja toisaalta kasvatettavan intentionaalisuus. Prosessinäkökohdalla Oelkers viittaa siis oppimis- tai sivistysprosessiin ja sen osuuteen pedagogisten toimintatilanteiden välttämättömänä osatekijänä ja teon käsitteellä kasvatukselliseen aktiviteettiin, joka tavalla tai toisella pedagogisesti tuottaa ja ohjaa näitä prosesseja (Oelkers 1985, 234-235; 247). Samalla hän sulkee pois sen mahdollisuuden, että kasvatusteot itsessään olisivat prosessi (mt. 170).

$\mathrm{T}$ ko- ja prosessikäsitteet eivät ole loogiselta rakenteeltaan identtisiä (ks. mt. 248). Ajatellaanpa vaikka opettamista (tekokategoria) ja oppimista (prosessikategoria). Nämä aktiviteetit eroavat toisistaan siinä, että a) niissä toimija on eri; b) toiminnan intentionaalisuus ei ole sama; c) toiminnan rakenne ei myöskään ole identtinen. Add: a) Opettaminen ja oppiminen ovat kahden eri henkilön - opettajan ja oppilaan toimintaa (ks. mt. 184). Add: b) Opettamisen tapauksessa toimija pyrkii saamaan aikaan muutoksen toisen henkilön oppimisprosessissa, kun oppimisen tapauksessa henkilö itse pyrkii tietoisesti oppimaan jotakin tai hän oppii maailmasuhteessa saamissaan kokemuksistaan ilman tietoista pyrkimystä oppimiseen (ks. mt. 223; 240; 171). Add: c) Opettaminen on oppijaan ja tämä oppimisprosessille konstitutiiviseen maailmasuhteeseen suuntautunutta toimintaa. Oppiminen puolestaan tapahtuu oppijan omassa maailmasuhteessa ja siinä saaduissa välittömissä kokemuksissa (ks. mt. 171).

$\mathrm{T}$ eko- ja prosessikategorioiden välinen erottelu on ulotettavissa myös kasvatuksen ja sosialisaation välisen suhteen tarkasteluun, sosialisaatiohan määritellään yleisimmin juuri prosessiksi. Pedagogisen toiminnanteorian perspektiivistä sosialisaatio on luonnehdittavissa sivistysprosessin käsitteen funktionaaliseksi ekvivalentiksi. ${ }^{4}$ Mielenkiintoisesti sosialisaatioteoreetikot ja -tutkijat Klaus Hurrelmann ja Dieter Ulich korostavat sosialisaatioteoreettisen lähtökohdan perustavan taustaoletuksen olevan “(...) että yksilölliset toimintakompetenssit rakentuvat aktiivisessa vuorovaikutuksessa sosaalisen ja esineellisen ympäristön kanssa. Tämä tapahtuu omaksumisena ja ja muokkaavana osallistumisena (mitgestaltende Teilnahme) ryhmän elämään, instituutioon tai yhteiskuntaan $(1991,4)$ ".

Cosialisaatio on mahdollista ymmärtää prosesSiksi, jossa yksilö omaksuu kulttuurisisältöjä ja mahdollisesti myös muokkaa tuossa oppimisprosessissa noita sisältöjä. Se perustuu yksilön toimintaan ja realisoituu yksilön ja maailman välisessä suhteessa. Sosialisaatio on siten jatkuva prosessi. Sille ominaista aikaulottuvuutta korostettaessa voidaan Antikaisen (1998, 101-104) tavoin käyttää käsitettä elämänkulku. Tämä käsite korostaa sosialisaation luonnetta alati jatkuvana elämänhistoriallisena prosessina (ks. myös Geulen 1991, 50). Kuten artikkelissani (1997, 4845) jo huomautin, sosialisaatioprosessin käsite laajasti ymmärrettynä on tältä osin identtinen si- 


\section{Sosialisaatio on mahdollista}

ymmärtää prosessiksi, jossa

yksilö omaksuu kulttuurisisältöjä

ja mahdollisesti myös tuossa

oppimisprosessissa muokkaa

niitä. Se perustuu yksilön

toimintaan ja realisoituu yksilön

ja maailman välisessä suhteessa.

Sosialisaatio on siten jatkuva

prosessi.

vistysprosessin käsitteen kanssa. Modernin sivistyskonseption mukaisesti sivistys on prosessi, joka todellistuu ihmisen ja hänen maailmansa välisessä vastavuoroisessa suhteessa. Siinä ihminen sekä reseptiivisyytensä varassa omaksuu kieltä, kulttuuria ja traditiota että spontaniteettinsa mahdollistamana myös itse omassa toiminnassaan muokkaa näitä ja siten samalla myös itseään (Benner 1991; 127-141; 1995, 92-104). Sekä sosialisaation käsitteeseen että sivistyskonseptioon sisältyy oletus siitä, että ihmisen ja maailman välisessä vuorovaikutuksessa ihminen kehittyy toimintakykyisenä subjektina, joka itse kykenee määrittelemään asemansa suhteessa kanssaihmisiin, kulttuuriin ja traditioon määrittyen kuitenkin persoonana kielen, sosiaalisten instituutioiden, kulttuurin ja tradition kautta (Hurrelman/Ulich 1991; Geulen 1991; Antikainen 1998, 117; Benner mt.; Kivelä 2000).

$\mathrm{S}$ osialisaation käsitteen tulkitseminen yksiuloteista (Hurrellmann/Ulich 1991, 9) tai "yltiösosiologista" (Antikainen 1998, 104) näkemystä laajemmin ja moniulotteisemmin lähentää sivistys- ja sosialisaatiokonseptioita huomattavasti toisiinsa. Hurrelmannin ja Ulichin mukaan sosialisaatioteoriassa on ihmisen ja tämän ympäristön välisen suhteen tarkastelun lähtökohtana oltava "produktiivisesti todellisuutta työstävän subjektin malli" (das Modell des produktiv realitätsarbeitenden Subjektes). Tällöin oletetaan, ettei sosiaalistuva subjekti yksipuolisesti määrity sosiaalisen ympäristönsä tai yhteiskun- nallisten struktuurien kautta. Sosialisaatioprosessia tarkastellaan persoonallisuuden kehittymisen subjektiivisten ja objektiivisten tekijöiden valossa, jolloin lähdetään siitä, että sosiaalistuva subjekti työstää omassa toiminnassaan sosialisaatioprosessille konstitutiivista maailmaa uudella tavalla määrittäen siten myös itse omaa kehittymistään refleksiivisesti. (Hurrelmann/Ulich 1991, 9-11; Geulen 1991, 44-45.)

Wilhelm von Humboldt - eräs modernin sivistysteoreettisen tradition perustajista - viittasi samaan ongelma-alueeseen ilmauksella "minän kietoutuminen maailmaan yleisimmäksi, elävimmäksi ja vapaimmaksi vuorovaikutukseksi" (die Verknüpfung unsres Ichs mit der Welt zu der allgemeinsten, regesten und freiesten Wechselwirkung) (von Humboldt Bennerin 1991, 131 mukaan). Tällä hän viittasi siihen, kuinka ihminen toisaalta toimii suhteessa maailmaan työstäen ja tulkiten sitä omasta yksilöllisestä perspektiivistään käsin. Ihmisen sivistysprosessi ei ole kuitenkaan ymmärrettävissä pelkästään ihmisen oman spontaniteetin ja autonomian ilmaukseksi, vaan se voi realisoitua vain suhteessa historiallisesti jo annettuun traditioon, kulttuuriin ja kieleen, jotka aina siten jo myös määrittävät yksilöllistä sivistysprosessia historiallisesti (Benner 1995, 103-104; ks. Kivelä 2000).

$\mathrm{K}^{\circ}$ oska sosialisaatiokonseptio on pedagogisen oiminnanteorian näkökulmasta ymmärrettävissä sivistyskonseptiolle identtisenä prosessikategoriana, voidaan kasvatustekojen ja sivistysprosessin välinen suhde määritellä kasvatustekojen ja sosialisaatioprosessin väliseksi suhteeksi (ks. Kivelä 1997). Tämän analyyttisen erottelun tarpeellisuus voidaan osoittaa tarkastelemalla sosialisaation käsitteen kahta tyypillistä käyttötapaa, jotka ovat omiaan aiheuttamaan käsitteellisiä ja teoreettisia epäselvyyksiä.

Esimerkiksi Ikonen käyttää sosialisaatiota sekä prosessi- että tekokategoriana: Sosialisaatioprosessissa yksilö omaksuu omassa toiminnallisessa maailmasuhteessaan kulttuurisisältöjä. Toisaalta sosialisaatio näyttää viittaavan myös intentionaalisiin tekoihin. Tämä ei selvennä sosialisaation käsitteen käyttöä puhumattakaan siitä, että kä- 
sitteiden kasvatus, pedagoginen toiminta ja sosialisaatio välinen yhteys selkeytyisi. Jos ymmärrämme sosialisaation kulttuurisisältöjen omaksumisena, on tietoinen sosialisaatio loogisesti tietoista kulttuurisisältöjen omaksumista. Tietoisesta sosialisaatiosta puhuttaessa ilmeisestikin viitataan kokonaan toiseen asiasisältöön, nimittäin tekoihin, joissa toimija ei tietoisesti pyri itse omaksumaan kulttuuria, vaan pyrkii tietoisesti saamaan aikaan toisen osapuolen sosialisaatioprosessin tai ohjaamaan sitä.

$\mathrm{K}$ äsitettä 'sosialisaatio' käytetään kahdessa merityksessä (SOSIALISAATIO' ja SOSIALISAATIO²). Sosialisaatio $^{1}$ viittaa prosessiin, jossa yksilö itse omaksuu kulttuurisisältöjä ja jopa omassa aktiivisessa toiminnassaan muokkaa tuossa omaksumisprosessissa kulttuuria. Sosialisaatio ${ }^{2}$ viittaa puolestaan intentionaalisiin tekoihin, joissa yksilön tavoitteena on vaikuttaminen toisen sosialisaatioprosessiin. Kuten huomaamme, on ensimmäisessä tapauksessa (sosialisaatio ${ }^{1}$ ) kysymys luonteeltaan eri aktiviteetista kuin toisessa tapauksessa $\left(\right.$ sosialisaatio $^{2}$ ). Mikäli lähtökohta on toiminnanteoreettinen (ks. Kivelä 1997, 55-56), on ilmeisestikin erotettava toisistaan kaksi eri toiminnan - ehkä jopa toimintaa ohjaavan rationaliteetin tai intentionaalisuuden - muotoa: kulttuurin omaksuminen omassa maailmasuhteessa realisoituvassa prosessissa ja toisen maailmasuhdetta ja siten tämän kulttuurin omaksumista määrittämään pyrkivät intentionaaliset teot. Lisäksi on välttämätöntä erottaa toisistaan kaksi eri toimijaperspektiiviä: kulttuuriin sosiaalistuvan yksilön ja tuota prosessia omilla teoillaan määrittämään pyrkivän perspektiivit. Erottelu on mahdollinen myös aikaulottuvuuden perusteella. Kulttuurin omaksuminen ja siinä tapahtuva yksilöllisyyden muotoutuminen jatkuu prosessina pohjimmiltaan läpi koko elämän, kun taas tuohon prosessiin vaikuttavat teot ovat ajallisesti ja paikallisesti eroteltavissa olevia opetus- ja kasvatustilanteita.

Kysymyksessä on kaksi toisistaan erotettavissa olevaa kategoriaa, joiden suhde ei ole määriteltävissä ala- ja yläkäsite -skeeman mukaisesti. Jo intuitiivisesti on selvää, ettei omaksuminen ole yläkäsite vaikuttamiselle. Sosialisaatio ${ }^{1}$ ei voi olla yläkäsite sosialisaatio 2 :lle, koska ensimmäinen on prosessikategoria ja toinen tekokategoria. $\mathrm{Ne}$ viittaavat kahteen erilaiseen aktiviteettiin, joilla on eri toimija. Käsitteellisen selvyyden vuoksi voimme korvata sosialisaatio ${ }^{2}$ :n käsitteen käsitteellä kasvatus, ilman että itse argumentaatiomalli muuttuu. Koska omaksumisesta (joka viittaa sosialisaation prosessimääritelmässä implikoituun yksilön ja maailman väliseen suhteeseen) ei voi johtaa loogisesti vaikuttamisen (joka viittaa toisen sosialisaatioprosessiin suunnattuihin vaikutusyrityksiin) käsitettä, lienee ilmeistä, ettei sosialisaation käsitteestä voi johtaa kasvatuksen käsitettä. ${ }^{5}$ Kysymys on kahdesta toisistaan käsitteellisesti erotettavissa olevasta toiminnan ulottuvuudesta: kulttuurin omaksumisesta (ja siinä tapahtuvasta kulttuurin representoimisesta; Kivelä 1997) ja kasvatuksellisesta vaikuttamisesta (ks. Oelkers 1985, 223; 243). Voimme edelleen syventää tätä kategorisointia käyttämällä modernin pedagogisen tradition tarjoamia käsitteitä kasvatus ja sivistys. Nämä ovat loogis-semanttisesti eri alaan kuuluvia käsitteitä, joiden analyyttinen erottelu on välttämätöntä. Yhtä vähän kuin sivistys on kasvatuksen yläkäsite, voi sosialisaatiokaan sitä olla.

Q osialisaatiota voi tapahtua ilman tietoisia kasSatustekoja, ja kasvatuksellisesta vaikutuksesta voi seurata sosiaalistumisprosesseja. Kasvatustekoja voi tapahtua myös ilman, että tapahtuu sosialisaatiota. Kasvatusteoilla pyritään toki intentionaalisesti saamaan aikaan oppimis- tai sosialisaatioprosessi. Tämä kasvatus/opetustoiminnan määrittelyn olennaisesti kuuluva tekijä erottaa sen sosialisaatiosta. Kasvatusteot eivät kuitenkaan ole sidoksissa siihen, tapahtuuko tosiasiallisesti sosialisaatiota vai ei. Näin kasvatuksen käsite on loogisesti riippumaton sosialisaation käsitteestä. Tästä seuraa edelleen se, että kasvatuksen ja sen myötä myös pedagogisen toiminnan käsite on määriteltävissä riippumatta sosialisaation käsitteestä.

Tämä analyyttinen erottelu ei kuitenkaan ratkaise ongelmaa siitä, miten kasvatustekojen ja sosialisaatioprosessien välinen suhde olisi teoreettisesti ja empiirisesti tarkasteltavissa. Esittelemäni (1997) periaateteoreettinen rekonstruktio voi 
antaa tämän ongelman tarkasteluun välineitä ilman, että joudumme puhumaan vaikutuksesta, vastavuoroisuudesta tai sopeutumisesta ja käyttämään siten käsitteitä, joilla ei ole sinänsä mitään eksaktia sisältöä.

\section{Lopuksi}

$\mathrm{K}$ asvatus, sivistys, pedagoginen toiminta ja sosialisaatio ovat käsitteellisiä konstruktioita, jotka mahdollistavat niiden ilmiöiden käsitteellistämisen, jotka liittyvät tai joiden katsotaan liittyvän ihmisen ja tämän ympäristön väliseen suhteeseen, jossa yksilö tulee kulttuurin ja yhteiskunnan jäseneksi. Yhtä vähän kuin pedagoginen toiminta on palautettavissa yksin kasvatukselliseen vaikuttamiseen, olisi se palautettavissa yksin sivistys- tai sosialisaatioprosessiin, koska kasvatuksellisen vaikutuksen aspekti ei yksiselitteisesti sisälly sosialisaatioprosessin käsitteeseen. Pedagogisessa toiminnassa ei ole kysymys pelkästään siitä, että toimijat kasvavat omassa toiminnassaan jonkin kulttuurin jäseniksi, vaan siihen sisältyy aina myös kasvatustekoja. Pedagogisen toiminnan käsite on teoreettinen konstruktio, jonka merkitys on siinä, että sen avulla on mahdollista käsiteanalyyttisesti tarkastella kasvatustekojen ja sivistysprosessin välistä suhdetta. Vaikka käsitteet kasvatus ja sosialisaatio viittaavatkin loogis-semanttisesti eri asiasisältöihin, voidaan pedagogisen toiminnan käsitteellä pyrkiä kuitenkin tematisoimaan sitä, miten kasvatukselliset vaikutukset ja sosialisaatioprosessit kietoutuvat institutionaalisissa, interaktiivisissa ja elämänhistoriallisissa konteksteissa toisiinsa. Pedagogisten toimintatilanteiden tarkastelun kannalta pelkkä sosialisaatiokonseptio - varsinkin siinä diffuusissa ja tarkemmin määrittelemättömässä muodossa, jossa Ikonen sitä mielellään käyttää - on riittämätön.

I kosen argumentointi perustuu ontologisoivalle oletukselle siitä, että on olemassa jokin tietty sosialisaatioprosessi reaalisena ilmiönä, kun taas pedagogiset käsitteet viittaavat tiettyihin sosialisaatiotapahtumiin, jotka ovat "tunnistettavissa" moraalisesti hyväksyttäviksi. Tämän argumentin perusteltavuutta voidaan epäillä jo siksi, ettei nykyisessä sosialisaatioteoreettisessa keskustelussa kirjoittajan edustama sosialisaation käsitteen ontologisointi näytä saavuttaneen varauksetonta hyväksymistä. Klaus Hurrelmann ja Dieter Ulich (1991) toteavat:

"Ei ole olemassa sosialisaatiota ('die' Sozialisation). On olemassa ainoastaan sosialisaatioteoreettinen kysymyksenasettelu, joka nousee yhteisön jäseneksi tulemisen problematisoimisesta (Problematisierung des Mitgliedwerdens). Tätä ei muuta puhetapaamme, joka jatkuvasti johtaa meitä harhaan ja käyttämään sosialisaatioteoreettisen kysymyksenasettelun tilalla epätäsmällistä käsitettä `sosialisaatio’.” (mt. 7.)

$\mathrm{H}$ urrelmannin ja Ulichiin nojautuen Ikosta voidaan kritisoida siitä, että hän kuvittelee virheellisesti jonkin tietyn - empiirisesti tunnistettavan olevan - ilmiön nimeltä "sosialisaatio" olemassaolon, johon nojautuen sosialisaatioteoria (ehkä jopa sosiologia) voisi osoittaa paikkaa kasvatuksen tai pedagogisen toiminnan käsitteelle ja teorialle lähinnä käytäntöön sitoutuneena normatiivisena teoriana tai moralisoivana puhetapana. Ainakin tässä yksittäisessä tapauksessa yritys kääntyy lopulta itseään vastaan, sillä se perustuu viime kädessä niin laaja-alaiseen määrittelyyn, että kaikki inhimillinen toiminta on nähtävä sosialisaatioksi. Perustellusti voidaan tietysti kysyä sitä, voiko edes sosialisaatiotutkimus nojautua näin määriteltyyn sosialisaation käsitteeseen. ${ }^{6}$

$\mathrm{K}$ äsitteiden kasvatus, sivistys ja pedagoginen iminta, välisten suhteiden määrittely on huomattavasti ongelmallisempaa, kuin mitä kirjoittaja näyttää olettavan. Tietysti kasvatuksen ja sosialisaation käsitteen voi määritellä Ikosen esittämällä tavalla. Tämä ei kuitenkaan mahdollista teko- ja prosessikategorioiden välisen suhteen selvittämistä, jolle käsitteiden kasvatus ja sivistys välinen erottelu voi antaa hyvän lähtökohdan. Sosialisaation käsitteen käyttöön näyttää liittyvän systemaattinen ongelma teko- ja prosessikategorioiden sekoittamisesta toisiinsa. Kirjoittajan artikkeli on tästä hyvä esimerkki. Hänen argumentaationsa oletettu kriittisyys perustuu juuri tämän erottelun huomiotta jättämiseen. Käytim- 
mepä näistä käsitteistä mitä hyvänsä, on teko- ja prosessikategorioiden välinen suhde ja sen adekvaatti käsitteellistäminen keskeinen ongelma. Sosialisaation todistelu yläkäsitteeksi vaikuttaa käsiteanalyyttisesti naiivilta strategialta eikä ratkaise tätä ongelmaa.

\section{Kirjallisuus}

ANTIKAINEN, A. (1998) Kasvatus, elämänkulku ja yhteiskunta. Porvoo: Wsoy.

BENNER D. (1991) Allgemeine Pädagogik. Eine systematisch-problemgeschichtliche Einführung in die Grundstruktur pädagogischen Denkens und Handelns. Weinheim und München: Juventa Verlag.

BENNER, D. (1995) Studien zur Theorie der Erziehung und Bildung. Pädagogik als Wissenschaft, Handlungstheorie und Reformpraxis. Band 2. Weinheim und München: Juventa Verlag

FRANK, M (1986) Die Unhintergehbarkeit von Individualität. Frankfurt am Main:Suhrkamp.

FRANK, M. (1991) Selbstbewusstsein und Selbsterkenntnis. Stuttgart: Philipp Reklam jun..

FRANK, M. (1996) Ist Subjektivität ein "Unding"? Über einige Schwierigkeiten der naturalistischen Reduktion von Selbstbewusstsein. Teoksessa: Krämer, S. (toim.) Bewustsein. Philosohischebeiträge, Frankfurt am Main: Suhrkamp, 66-91

GEULEN, D. (1991) Die historische Entwicklung sozialisatiostheoretischer Ansätze. Teoksessa: Hurrelmann, K. / Ulich, D (toim.) Neues Handbuch der Sozialisationsforschung. Weinheim und Basel: Beltz, 21-54

HURRELMANN K./ ULICH, D (1991) Gegenstand- und Methodenfragen der Sozialisationsforschung. Teoksessa: Hurrelmann, K. / U., Dieter (toim.) Neues Handbuch der Sozialisationsforschung. Weinheim und Basel: Beltz, 2-20.

HABERMAS, J. (1989) Nahchmetaphysisches Denken. Frankfurt am Main: Suhrkamp

KIVELÄ, A. (1997) Pedagoginen toiminnanteoria ja sosialisaatioteoria. Teoksessa: Siljander, P. (toim.) Kasvatus ja sosialisaatio. Tampere: Gaudeamus, 32-65.

KIVELÄ, A (1998). Gibt es noch eine Theorie pädagogischen Handelns? Zeitschrift für Pädagogik 44, 4, 603-616.

KIVELÄ, A. (2000) Sivistys, kasvatus ja pedagoginen toiminta - Subjektifilosofiasta pedagogisen toiminnan teoriaan. Teoksessa: Siljander, P. (toim.) Kasvatus ja sivistys. Tampere: Gaudeamus (painossa)

MOLLENHAUER, K. (1982) Theorien zum Erziehungsprozess. München: Juventa Verlag.

OELKERS, J. (1982) Intention und Wirkung: Vorüberlegungen $\mathrm{zu}$ einer Theorie pädagogischen Handelns. Teoksessa: Luhmann, N./Schorr, E. (toim.) Zwischen Technologie und Selbstreferenz. Fragen an die Pädagogik. Frankfurt am Main: Suhrkamp, 139-194.

OELKERS, J. (1985) Erziehen und Unterrichten. Grundbegriffe der Pädagogik in analytischer Sicht. Darmstadt: Wissenschafliche Buchgesellschaft.
OSER, F. (1994) Zu-Mutung: eine basale pädagogische Handlungsstruktur. Seibert, N./Serve, H.J (toim.) Bildung und Erziehung an der Schwelle zum dritten Jahrtausend. München: PimS-Verlag, 773-800.

TUGENDHAT, E. (1993) Selbstbewusstsein und Selbstbestimmung. Sprachanalytische Interpretationen. Frankfurt am Main: Suhrkamp

\section{Viitteet}

1 Tämä ei tarkoita sitä, etteivätkö normatiiviset kasvatusopit tai käytännölliset pedagogiikat olisi tarpeen puhumattakaan siitä, että ne olisivat mielettömiä. Hahmottelemani pedagogisen toiminnan teoria ei vain ole sidottavissa mihinkään spesifeihin sivistysideaaleihin, kuten kirjoittaja virheellisesti olettaa.

2 Yhdyn kirjoittajan kantaan siitä, että autonomia $\angle$ on käsitteenä ongelmallinen. Autonomian käsitettä ei ole tarpeen kuitenkaan tällä tasolla määritellä joidenkin spesifien psyko-sosiaalisten dispositioiden avulla.

3 Puhuessaan prosessikäsitteistä Oelkers käyttää pääsääntöisesti käsitteitä oppiminen tai sivistys.

$\triangle$ Oppimisen ohella Oelkers käyttää prosessikäsit teenä myös käsitettä initiaatio (1985, 224-225), joka on merkitykseltään varsin lähellä sosialisaatiota. Prosessikäsitteistä sivistys on laajin. Sivistysprosessit ovat yhtä lailla oppimisprosesseja, initioitumista ja sosialisaatiota yhteiskunnallistetun toimintakykyisen subjektin kehittymisen merkityksessä (vrt. Geulen 1991, Hurrelmann/Ulich 1991). Lisäksi sivistyskäsitteeseen voidaan liittää kontrafaktuaalinen regulatiivi tai metanormi ihmisyyden korkeammasta sivistyksestä (Höherbildungg der Mencheit), joka ei kuitenkaan sivistyksen prosessimääritelmää käytettäessä ja pedagogisen toiminnan muodollisista aspekteista keskusteltaessa enää edellytä minkään konkreettisen historianfilosofisen ideaalin muotoilemista.

5 Toki on mahdollista esittää normatiivinen argu $\mathcal{~ m e n t t i ~ s i i t a ̈ , ~ e t t a ̈ ~ k a s v a t u k s e n ~ t u l e e ~ s a a d a ~ a i - ~}$ kaan yhteiskuntaan ja sopeutumisen prosessi ja pitää sitä yllä. Tämä ei kuitenkaan kerro mitään siitä, millaista toimintaa pedagoginen toiminta on tai mikä on kasvatuksen suhde sosialisaatioprosessiin. (vrt. Oelkers 1985,234 .)

6 Esimerkkinä mainittakoon, että Hurrellmanin ja Ulichin (1991) toimittama sosialisaatiotutkimuksen standarditeos "Neues Handbuch der Sozialisationsforschung" tuntee vähintäänkin kymmenkunta erilaista sosialisaatioteoreettista lähtökohtaa, jotka ulottuvat käyttäytymisteorioista rooli- ja interaktioteorioiden kautta aina elämänkulun käsitteen lähtökohdakseen ottaviin näkemyksiin.

Laatikoidut tekstilainaukset eri sivuaukeamilla ovat toimituksen valitsemat. 